\title{
Asymmetric effect of government debt on GDP growth: evidence from Namibia
}

\author{
TEBOHO JEREMIAH MOSIKARI, Ph.D.* \\ JOEL HINAUNYE EITA, Ph.D."
}

Article $^{* *}$

JEL: B22, C05, C22, E62

https://doi.org/10.3326/pse.45.4.7

\footnotetext{
* The authors would like to thank two anonymous reviewers whose comments helped improve and clarify this manuscript.

${ }^{* *}$ Received: September 7, 2020

Accepted: July 12, 2021
}

\section{Teboho Jeremiah MOSIKARI}

Department of Economics, North-West University, Private Bag X2046, Mmabatho, 2735, South Africa e-mail: tebohomosikari@gmail.com

ORCiD: 0000-0001-8552-1566

\section{Joel Hinaunye EITA}

School of Economics, College of Business and Economics, University of Johannesburg, P.O. Box 524, Auckland Park, Johannesburg, 2006, South Africa

e-mail: jeita@uj.ac.za,hinaeita@yahoo.co.uk ORCiD: 0000-0002-5859-7132 


\section{Abstract}

This study investigates the asymmetric relationship between government debt and GDP growth in Namibia. The study applied the non-linear autoregressive distributed lag (NARDL) methods to determine the asymmetrical effect of government debt on GDP growth. The estimated long-run parameters for positive and negative shocks of government debt are -0.104 and -0.738 , respectively. The results suggest that a 1\% increase in debt will be followed by a 0.104 decrease in GDP growth and that a $1 \%$ decrease in debt will produce a 0.738 increase in economic growth. This shows that the responsiveness of GDP growth to positive values of debt is different to that of negative values of debt. The responsiveness of GDP growth to negative values of debt is greater than to positive value of debt. This implies that it is important for Namibia to have manageable debt and fiscal sustainability in order to increase its GDP growth.

Keywords: government debt, economic growth, nonlinear, fiscal policy, Namibia

\section{INTRODUCTION}

The term government debt can be described as how much a particular country owes to lenders outside of itself. These lenders may include private individuals, businesses, institutions, and even other governments. The term "government debt" in the literature is often used interchangeably with the term sovereign debt or public debt (Amadeo, 2020). The literature widely acknowledges that there are a number of channels through which public debt is likely to hamper long term economic growth. Channels through which government debt have an impact on economic growth are saving and investment, total factor productivity and interest rate. According to Checherita-Westphal and Rother (2011) the crucial channel through which government debt accumulation can affect growth is that of long-term interest rates. Higher long-term interest rates emanating from more debt-financed government budget deficits, can crowd out private investment, thus dampening potential output growth. This is stated by Égert (2012) who argued that the increase in taxation needed to service a higher government debt crowds out private investment through reduction of disposable income and saving and a rise in the distortionary costs of taxation. The other channel is the aftermath of high government debt to GDP ratio. This ratio of debt has often given rise to fears that the government will cancel its debt by printing more money to produce hyperinflation. However, it is clear from theoretical and empirical literature that this form of financing produces a decrease in the purchasing power of the domestic currency. Furthermore, borrowing or financing of government debt by means of printing money is not an option for the Namibian economy because the country has chosen to link its currency to the South Africa rand. According to Sherbourne, Nampila and du Preez (2002), this is within the framework of the Common Monetary Area (CMA).

Namibia's government debt has increased at a faster rate than GDP growth since its independence in 1990. In the year 2002, the Government of Namibia stipulated in 
its National Development Plan (NDP) II and the Medium Term Expenditure Framework (MTEF) that government debt to GDP ratio should not exceed $25 \%$. Figure 1 presents the trends in government debt of Namibia for the period 1981 to 2019.

\section{Figure 1}

Namibian government debt as a percentage of GDP, 1981-2019

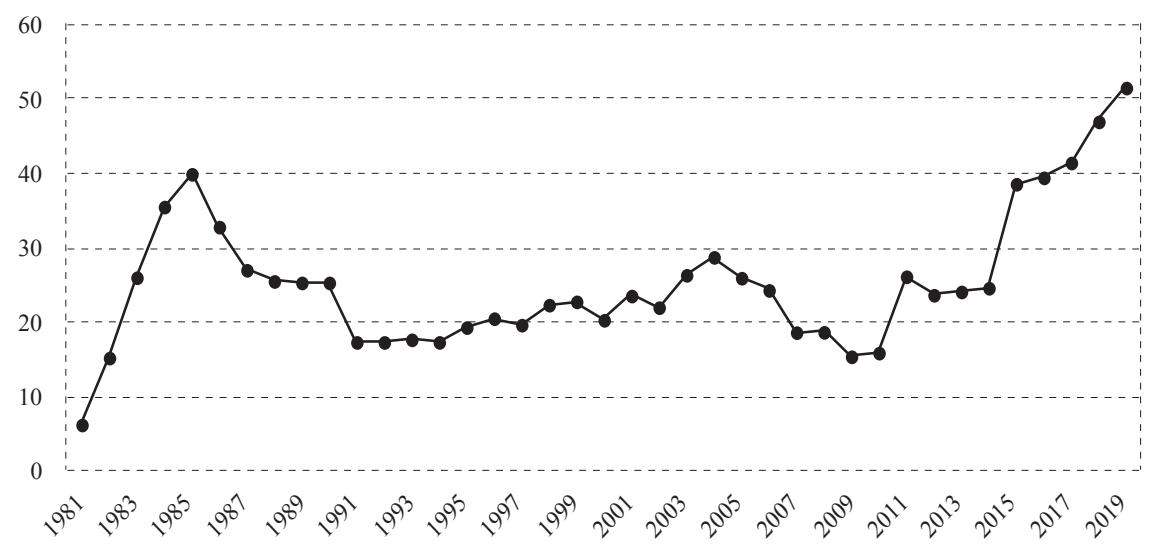

Source: Own compilation using data from IMF.

Figure 1 shows that government debt increased sharply between 1980 and 1985 . It reached a peak of $40 \%$ in 1985 . It then decreased to $17.4 \%$ in 1991 . Furthermore, figure 1 shows that government debt as percent of GDP steadily increased from $17 \%$ in 1993 to $28.4 \%$ in 2005 . The debt ceiling of $25 \%$ to GDP as outlined in NDP II and MTEF was relaxed in order to take account of the development needs of the country. In 2005 the government of Namibia approved the Sovereign Debt Management Strategy (SDMS), which was aimed at curbing borrowing and ensuring that the debt ratio does not exceed 35\% of GDP (AEO, 2012). The SDMS seems to have been successful in reducing government debt, for it fell from $28.8 \%$ in 2005 to $16.4 \%$ of GDP in 2010. The effect of SDMS in reducing government debt was negated by the effect of the global economic and financial crisis of 2009. The ratio of government debt to GDP increased rapidly from $16.4 \%$ in 2010 to $51.5 \%$ in 2019. According to ECORYS (2018) this sudden increase in public debt brought with it substantial increases in the cost of debt service, which is currently putting severe pressure on the government's budget. The growth in government debt shrinks the little surplus public debt capacity, and this raised concern that the government may not be in a position to stimulate growth through fiscal expansion (Deloitte, 2019). As expected, the interest payments have also increased due to increased government debt. Interest payment has increased significantly from 7\% of total expenditure in 2015 to 14\% in 2017 (ECORYS, 2018). Government debt is one of the critical components of growth effect in the long-run for Namibia.

Previous studies (such as Amwaama, 2018; Zaaruka, 2007; and Kaakunga, 2006) that investigated the role of government debt on economic growth in Namibia assumed a linear relationship between variables. They did not test the nonlinear 
relationship between government debt and economic growth in Namibia. Empirical studies on the nonlinear relationship between government debt and economic growth in Namibia are limited or nonexistent. Modelling the relationship between economic growth and government debt through the assumption of linearity might lead to biased results. This might lead to wrong inferences being made from the results. Hence, it important to test the nonlinear relationship between government debt and economic growth. Therefore, the objective of this study is to estimate the asymmetric relationship between government debt and GDP growth in Namibia. The study uses nonlinear autoregressive distributive lag (NARDL) for this purpose. This is contrary to previous studies conducted on Namibia. The NARDL approach also allows for testing whether government debt changes have symmetric or asymmetric effects on economic growth. In order to understand the nexus between government debt and GDP growth, two issues are addressed in this paper. The first one is whether the relationship between government debt and economic growth in Namibia is symmetrical or asymmetrical. The second is the responsiveness of GDP growth to positive and negative effects of government debt. The rest of the study is organized as follows. Section 2 presents a review of the literature. Section 3 discusses the empirical model, data and estimation technique. Section 4 presents estimation results. Section 5 concludes the paper.

\section{LITERATURE REVIEW}

There is an extensive literature on the relationship between government debt and economic growth. The relationship between these two variables has been investigated in both developed and developing countries. There are cross section or panel data studies on the relationship between government debt and economic growth in both developed and developing countries. Eberhardt and Presbitero (2015) investigated the relationship between government debt and economic growth in a panel of 118 developing, emerging and advanced economies over the period 1960 to 2012. The study found that the relationship between the two variables is negative. Bilan and Ihnatov (2015) examined the effect of government debt on economic growth for 28 European Union (EU) member states during the period 1990-2011. The study used a non-linear (quadratic) model. The study established that there is an "inverted U" relationship between public debt and economic growth, with a maximum debt threshold of about $94 \%$ of GDP for the whole group of 28 European Union member states.

Reihnart and Rogoff (2010a; 2010b) investigated the relationship between debt and real GDP growth in 44 countries for a period of 200 years. The study used a dataset which has 3,700 observations. The period of estimation has different political systems. exchange rate arrangements, historical circumstances and institutions. The study finds that the relationship between debt and real GDP growth depends on the level of debt to GDP ratio. When debt to GDP ratio is below 90 percent, the relationship between debt and GDP growth is very weak. However, when debt to GDP ratio is more than 90 percent, the relationship becomes negative. This means that an increase in debt will cause real GDP growth to decrease. This is for advanced economies. Emerging economies have a threshold lower than 
that of advanced economies. The threshold for emerging economies is at 60 percent. The results indicate that for emerging economies, when debt to GDP ratio is above 60 percent, the relationship between the two variables is negative. At a debt to GDP ratio of above 60 percent, real GDP growth will be reduced by 2 percent. Reinhart and Rogoff (2011) investigated the relationship between economic growth and debt in advanced economies. Advanced economies have been experiencing a rise in debt since the period before the Second World War. Historical evidence suggests that a rise in debt is associated with low real GDP growth.

Hussain, Haque and Igwike (2015) examined the relationship between public debt and economic growth for 48 countries in Sub-Saharan Africa, using the dynamic Arellano-Bond panel data estimation for the period 1995 to 2012. The study found that there is a negative correlation between government debt and economic growth. There are also single country studies on the effect of government debt on economic growth in both developed, emerging and developing countries. For example, Misztal (2010) used an vector autoregression (VAR) model for individual countries in the EU for the period 2000-2010. The results indicate that the impact of public debt on economic growth is significantly different in the individual EU member countries. In some countries there is a negative and in others an insignificant relationship between the two variables. Checherita-Westphal and Rother (2011) examined the relationship between the two variables for 12 euro area countries using 2-stage least squares. The results show that a public debt threshold of $90-100 \%$ of GDP is an average for those euro countries.

Burhanudin et al. (2017) found that there is no evidence to conclude that the level of government debt had any adverse impacts on sustainable economic growth in Malaysia. However, Abd Rahman (2012) used quarterly data for the period 2000 to 2011. The results indicate that high domestic debt does have negative impact on economic growth in the long-run. Baaziz et al. (2015) examined the relationship between inflation rate, trade openness, public debt and real GDP in South Africa using a nonlinear smooth transition regression (STR) model. The results revealed that government debt becomes adverse to economic growth when it reaches the limit of $31.37 \%$ of GDP. Using the ADL test for threshold cointegration Cai (2017) shows that cutting public debt could obviously benefit China's economic growth in the long run. Pegkas (2018) examines the effect of public debt on economic growth in Greece. The results reveal that public debt has a negative impact on economic growth and that above the threshold of $105 \%$ of debt to GDP, the effect becomes more significantly negative. The empirical literature modelled the relationship between GDP growth and debt, showing that there is a direct relationship between debt and GDP growth. Although there could be channels through which debt impacts GDP growth, the empirical literature suggests a direct relationship between the two variables.

Despite the fact that public debt is one of the important variables in the determination of economic growth for most economies, empirical studies on Namibia are limited. However, there are five studies on the relationship between public debt and economic growth in Namibia. Sherbourne, Nampila and du Preez (2002) is 
the first empirical study that assessed fiscal policy trends for the period 1992/93 to $2001 / 02$. It then analysed the sustainability of the government's current fiscal path. It concludes that the government in Namibia generally borrows because of difficulties in forecasting cash flows. Increasing public debt through borrowing enables the government to finance its expenditure. Zaaruka, Ndove and Tjipe (2004) was the second study to investigate whether the behavior of debt in Namibia is consistent with fiscal sustainability. It revealed that the Namibian government may find it difficult to service its debt in the near future. Therefore, it urged that government should try to remain below the targeted limits of public debt in order to leave room to maneuver in difficult times. Kaanguga (2006), the third study investigated the impact of fiscal policy on economic growth. The study used a simple Engle-Granger method to investigate the role of government on the economy. The findings of the study are that there is a negative relationship between fiscal deficit, total public debt and growth. The fourth study was that of Zaaruka (2007) who assessed the role of the threshold effect of public debt on economic growth in Namibia. The paper used linear and nonlinear regression to determine the threshold relationship between public debt and economic growth and the results indicate the threshold level for public debt to have an effect on economic growth is about 38\%. Nakale, Sikanda and Mabuku (2015) evaluated growth determinants in Namibia applying the framework of growth accounting. The study indicated that fiscal reforms must be enforced to address the high level of government expenditure and debt, which can pose a threat to macroeconomic stability. Amwaama (2018) assessed the relationship between budget deficit and economic growth in Namibia. The paper employs the Auto Regressive Distributed Lag (ARDL) bounds test and used quarterly data spanning from 1993Q4 to 2015Q5. The results indicate that budget deficit negatively affects growth rate in both the short and the long run. This study differs from previous research conducted on the relationship between government debt and economic growth in Namibia. The current study makes its contribution in the following ways. Firstly, it applies current robust econometric methods to investigate the relationship between government debt and GDP growth in order to make informed policy recommendations. This approach is different from the study by Sherbourne, Nampila and du Perez (2002) and Nakale, Sikanda and Mabuku (2015), which were much more interested in analyzing the trends of fiscal sustainability in Namibia and did not apply robust econometric methods. Secondly, it investigates non-linearity between variables before applying any non-linear technique such as regression or NARDL. Such an approach is critical in ensuring that there is no wrong model specification. Zaaruka (2007) applied non-linear regression to investigate the relationship between fiscal policy (debt) and economic growth. However, the study failed to first test the presence on non-linearity among the variables. It also did not apply recent non-linear unit root tests to determine the order of integration. Such an approach may lead to inappropriate results. This current study, therefore fills the gaps and address the shortcomings of previous studies by assessing the effect of negative and positive values of government debt on GDP growth, which are assumed to be nonlinear in nature. 
Following a review of the empirical literature, this paper adopts and modifies the empirical model that was applied by Amwaama (2018). The empirical model is written as follows:

$$
G D P_{t}=f\left(D B T_{t}, L A R G_{t}\right)
$$

Where $G D P_{t}, D B T_{t}$ and $L A R G_{t,}$ are gross domestic product, total government debt and share of agriculture in the economy. Equation (1) is transformed into natural logarithms as follows:

$$
L G D P_{t}=a_{1}+\beta_{1} L D B T_{t}+\beta_{2} L A R G_{t}+\pi_{t}
$$

Where $\pi_{t}$ represents residuals, and all other variables are as previously defined. Economic theory suggests that as government debt rises, it increases the burden for the government of servicing the national debt. This will, in the long-run, reduce the available fiscal resources, which will ultimately reduce GDP growth prospects. Therefore the effect of government debt on GDP growth is expected to be negative. There is an expected positive relationship between the share of agriculture in the economy and economic growth. It is expected that as the agricultural share increases (especially for food importing countries such Namibia) it will strengthen domestic supply of food, which will ultimately increase income through a rise in consumption.

\subsection{DATA}

The study uses annual data and covers the period of 1980 to 2019. The data were collected from various sources in order to estimate equation (2). The estimation period is selected based on the availability of data. Economic growth (GDP) is proxied by percentage change in GDP at constant prices. The share of agriculture (AGRIC) is proxied by the share of agriculture, fishery and forestry in GDP, and the data for this variable was collected from the World Bank's World Development Indicators (WDI). The data for debt to GDP ratio (DBT) was sourced from the Ministry of Finance of Namibia.

\subsection{ESTIMATION TECHNIQUE}

This study applies the nonlinear autoregressive distributive lag model (NARDL) in order to investigate whether there is an asymmetric relationship between government debt and GDP growth in Namibia. The study follows Shin, Yu and Greenwood-Nimmo (2014) who developed the NARDL model where the variables in the equation (government debt and agriculture value added) can be decomposed into negative and positive partial sums. Therefore, equation (2) is specified in nonlinear form as follows: 


$$
\begin{aligned}
\Delta L G D P_{t}= & \alpha_{0}+\beta_{1} L G D P_{t-1}+\gamma_{1}^{-} L D B T_{t-1}^{-}+\gamma_{2}^{+} L D B T_{t-1}^{+}+y_{3} L A R G_{t-1} \\
& +\gamma_{5}^{-}+\sum_{i=1}^{p-1} \theta_{i} \Delta L G D P_{t-i}+\sum_{i=0}^{q} \pi_{1}^{+} \Delta L D B T_{t-i}^{+} \\
& +\sum_{i=0}^{q} \pi_{2}^{-} \Delta L D B T_{t-i}^{-}+\sum_{i=0}^{q} \pi_{3} \Delta L A R G_{t-i}+\mu_{t}
\end{aligned}
$$

Where $q$ and $p$ are lag orders in equation (3) and long run coefficients are computed as $\beta_{2}=\gamma^{-} / \beta_{1}$ and $\beta_{3}=\gamma^{+} / \beta_{1}$. In addition, $\sum_{i=0}^{q} \pi_{i}^{+}$captures the short run impact of government debt increase on GDP growth, while $\sum_{i=0}^{q} \pi_{i}^{-}$captures the short run impact of government debt reduction on GDP growth. To determine the long-run cointegration between government debt and GDP growth, this paper uses the stepwise OLS procedure to estimate equation (3) which uses a general-tospecific method. To estimate the model using NARDL, the study performs a test for long-run cointegration using the bounds testing approach (Pesaran, Shin and Smith, 2001). The null hypothesis states that the effect is symmetrical if $y_{1}=y_{2}=$ $y_{3}=0$. This implies that there is no asymmetric cointegration. The alternative hypothesis states that the effect is asymmetrical if $y_{1} \neq y_{2} \neq y_{3} \neq 0$. This suggest that there is asymmetric cointegration. Then the study applies Wald F-test statistics to determine if there is asymmetric cointegration between government debt and GDP growth in Namibia. However, before determining whether a long run relationship among the variables does exist, the study needs to investigate whether the variables in the study are suitable for nonlinear modelling. The study uses the test of Brock et al. (1996) or BDS for that purpose. The purpose of the test is to determine the null hypothesis of linearity in the model. The study follows Breitung (2002) and Bierens (1997) to test for the nonlinear unit root of the variables.

\section{EMPIRICAL RESULTS}

\subsection{DESCRIPTIVE STATISTICS}

Descriptive statistics are the first step in empirical analysis. Table 1 presents the descriptive statistics of the variables used in the study. The results show that on average GDP growth between the years 1980 to 2019 is 3.03\%. On the other hand, government debt and the share of agriculture have the mean values of $21.18 \%$ and $20.45 \%$, respectively.

\begin{tabular}{|c|c|c|c|}
\hline & GDP & DBT & LARG \\
\hline Mean & 3.03 & 21.18 & 20.45 \\
\hline Maximum & 12.26 & 40.00 & 20.88 \\
\hline Minimum & -1.82 & 3.00 & 20.10 \\
\hline Standard deviation & 2.96 & 6.63 & 0.21 \\
\hline
\end{tabular}

\section{TABLE 1}

Descriptive statistics

Source: Computed by the authors.

To extend on the preliminary analysis, this study also computed the Spearman pairwise correlations. The results are presented in table 2, which shows the 
coefficients and p-values for each pairwise variable. It indicates that there is a positive pairwise correlation between GDP growth and agricultural share with a coefficient of 0.54 . However, there is a negative pairwise correlation between government debt and GDP growth with insignificant coefficient of 0.06.

TABle 2

Pair-wise correlation matrix

\begin{tabular}{|c|c|c|c|}
\hline $\begin{array}{l}\text { Correlation } \\
\text { (probability) }\end{array}$ & GDP & DBT & LARG \\
\hline GDP & $\begin{array}{c}1.00 \\
-\end{array}$ & & \\
\hline DBT & $\begin{array}{l}-0.06 \\
(0.68)\end{array}$ & $\begin{array}{c}1.00 \\
-\end{array}$ & \\
\hline LARG & $\begin{array}{c}0.54 \\
(0.00)\end{array}$ & $\begin{array}{c}0.05 \\
(0.77)\end{array}$ & $\begin{array}{c}1.00 \\
-\end{array}$ \\
\hline
\end{tabular}

Note: p-values are in brackets.

Source: Computed by the authors.

\subsection{NONLINEARITY TEST}

Since the objective of this study is to determine the asymmetric relationship between government debt and economic growth in Namibia, it is important to investigate nonlinearity among the variables. The study used the commonly known test of BDS to investigate the nonlinearity in the variables. The results are presented in table 3 . Table 3 shows that the null hypothesis of linearity is rejected. It is rejected in favour of nonlinearity. The results imply a non-normal distribution of the variables, which gives some evidence of nonlinearity.

TABLE 3

BDS test for nonlinearity

\begin{tabular}{|c|c|c|}
\hline Variable & Dimension & BDS statistics \\
\hline \multirow{5}{*}{ LGDP } & 2 & 0.188 \\
\hline & 3 & 0.310 \\
\hline & 4 & 0.390 \\
\hline & 5 & 0.445 \\
\hline & 6 & 0.480 \\
\hline \multirow{5}{*}{ DBT } & 2 & 0.144 \\
\hline & 3 & 0.246 \\
\hline & 4 & 0.323 \\
\hline & 5 & 0.363 \\
\hline & 6 & 0.383 \\
\hline \multirow{5}{*}{ LARG } & 2 & 0.124 \\
\hline & 3 & 0.211 \\
\hline & 4 & 0.261 \\
\hline & 5 & 0.287 \\
\hline & 6 & 0.297 \\
\hline
\end{tabular}

Note: Probability for all dimensions is zero.

Source: Computed by the authors. 
The next step is to test for unit root in the variables. The study uses an unconventional test of unit root that is specifically suitable if the data depicts the non-normality over time. The study performs the test of nonlinear unit root using the Breitung and Bierens unit root tests. The results are presented in table 4 .

TABLE 4

Nonlinear unit root test

\begin{tabular}{|c|c|c|c|c|}
\hline \multirow{2}{*}{ Variables } & \multicolumn{2}{|c|}{ Breitung test } & \multicolumn{2}{|c|}{ Bierens test } \\
\hline & t-statistics & p-values & Coefficient & t-statistics \\
\hline LGDP & -0.386 & 0.200 & -0.058 & -0.110 \\
\hline LDBT & 0.003 & 0.025 & -0.263 & -0.530 \\
\hline LARG & 0.067 & 0.400 & 0.007 & 0.420 \\
\hline
\end{tabular}

Source: Computed by the authors.

The results from the Breitung test indicates that LDBT is stationary at levels, but the levels in LGDP and LARG are nonstationary. This means that LGDP and LARG are integrated of order one. The results of the Bierens unit root test confirms that all variables are nonstationary in levels, which means that they have unit root. Therefore, the results of Bierens test confirm that all variables are integrated of order one $I(1)$ in the presence of nonlinearity. The next step is to determine the nonlinear ARDL cointegration among the variables.

This study applies the NARDL cointegration test on an unrestricted model. It uses the F-test on the joint hypothesis that the parameters of the lagged long run are jointly equal to zero. The results are presented in table 5 . The results confirm statistically the evidence of long-run cointegration among the variables. The results indicate that the computed F-statistic of 13.513 is greater than the critical value of upper bound 5.61 at $1 \%$ significance level. The results imply that there is a long run relationship between government debt and GDP growth in Namibia.

\section{TABLE 5}

NARDL bounds cointegration results

\begin{tabular}{|c|c|c|}
\hline Critical value (\%) & Lower bound (0) & Upper bound I(1) \\
\hline 1 & 4.29 & 5.61 \\
\hline 5 & 3.23 & 4.35 \\
\hline 10 & 2.72 & 3.77 \\
\hline NARDL F-statistics & \multicolumn{2}{|c|}{ Wald F-stats $-13.513 * * *$} \\
\hline
\end{tabular}

Notes: *** 1\% significance level, **5\% significance level, *10\% significance level. Null hypothesis: no asymmetric cointegration. Alternative hypothesis: asymmetric cointegration.

Rejection rule: reject null hypothesis if F-statistics is greater than the upper limit.

Source: Computed by the authors.

Since there is evidence of nonlinear cointegration, the next step is to present the long run parameters of NARDL regression. The results are presented in table 6 . Empirically, the non-linear ARDL specification having lags 1, 3, 0, 2 are selected 
based on the AIC. It shows that the decomposed positive effects of government debt (DBT_POS) are insignificant, whereas decomposed negative effects of government debt (DBT_NEG) are significant. The estimated long-run parameters for positive and negative shocks of government debt are -0.104 and -0.738 , respectively. It is therefore clear from the results that the responsiveness of GDP growth to negative is stronger than to positive values of debt. The results show that a $1 \%$ increase in government debt will cause GDP growth to decrease by $0.104 \%$, but this coefficient is statistically insignificant. A decrease in debt is associated with an increase in GDP growth by $0.738 \%$. The results further show that there is a positive and significant effect of the share of agriculture on GDP growth. The results imply that a $1 \%$ increase in the agricultural share will result in an $18.4 \%$ increase in GDP growth. The estimated model has an acceptable adjusted $\mathrm{R}$-squared value. After estimating the NARDL long run parameters, the study also estimates a short-run model and diagnostic tests were carried out to assess the robustness of the model. The short run results are presented in table 7.

TABLe 6

NARDL long-run parameter estimation

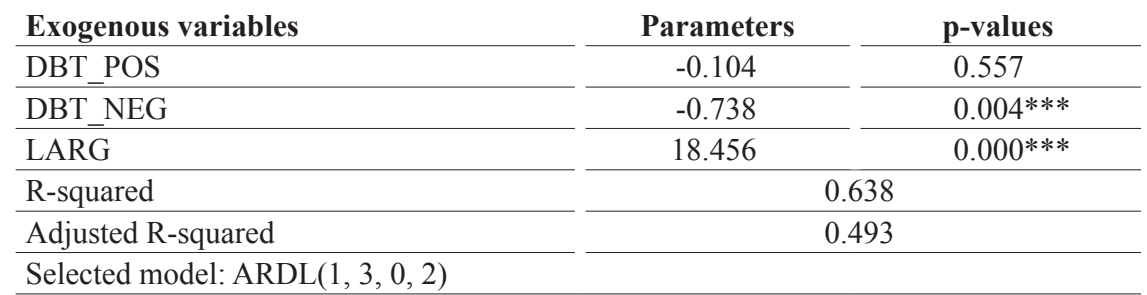

Notes: *** 1\% significance level, **5\% significance level, *10\% significance level. Dependent variable: $D(G D P)$.

Source: Computed by the authors.

Table 7 presents the short run and residual diagnostic results. The error correction term or Ect (-1) term determines the speed of adjustment to equilibrium. Table 7 shows that the coefficient of the error correct term is negative and statistically significant. It is greater than 1 , which indicates that there is over-adjustment to equilibrium. Table 7 also indicates that the results passed diagnostic statistics. Furthermore, the study tested for the stability of the model estimated. The results in figure 2 shows that both the CUSUM and the CUSUM of squares confirm that the model is stable. 
TABle 7

Short run NARDL estimation

Exogenous variables

$\mathrm{C}$

@TREND

$\Delta$ (DBT_POS)

$\Delta$ (DBT_POS(-1)

$\Delta$ (DBT_POS(-2)

$\Delta$ (LARG)

$\Delta$ (LARG(-1)

Ect (-1)

R-squared

\begin{tabular}{|c|c|}
\hline Parameters & p-values \\
\hline-384.474 & $0.000 * *$ \\
\hline-0.950 & $0.000 * * *$ \\
\hline 0.196 & 0.302 \\
\hline-0.027 & 0.879 \\
\hline 0.672 & $0.000 * * *$ \\
\hline 11.351 & $0.002 * * *$ \\
\hline 7.227 & $0.039 * *$ \\
\hline-1.033 & $0.000 * * *$ \\
\hline \multicolumn{2}{|c|}{0.759} \\
\hline \multicolumn{2}{|c|}{0.699} \\
\hline
\end{tabular}

Adjusted R-squared $0.862(0.435)$

Heteroskedasticity Test: Breusch-Pagan-Godfrey $82.240(0.000)$ Jarque-Bera test $0.449(0.906)$

Breusch-Godfrey Serial Correlation LM Test

Notes: *** 1\% significance level, **5\% significance level, *10\% significance level. p-values are in brackets. Dependent Variable: $D(G D P)$.

Source: Computed by the authors.

\section{Figure 2}

\section{Stability diagnostics}
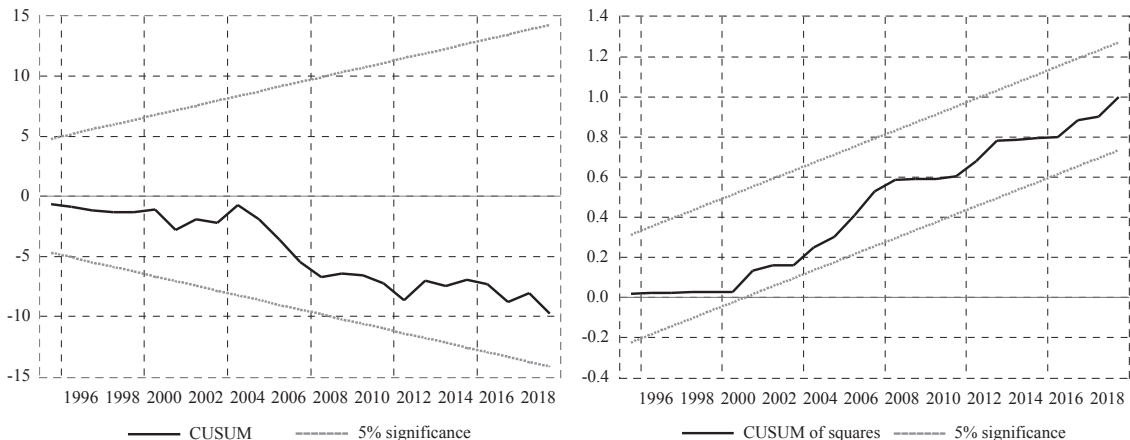

Source: Computed by the authors.

The study investigated further whether the coefficients in the long run and short run are symmetrical or asymmetrical. The results for an asymmetrical test are presented in table 8 . It is evident from table 8 that decomposed positive and negative effects of government debt on GDP growth are significant at $1 \%$. This implies that the study rejects the null hypothesis of no asymmetry. This suggests that there is inequality, and that the coefficients are not the same. 
Long-run and short run asymmetric test

\begin{tabular}{lcl} 
Asymmetric test & F-statistics & p-value \\
\hline Long run $-\gamma_{1}^{-} / \beta_{1}=-\gamma_{2}^{+} / \beta_{1}$ & 7.011 & $0.0081^{* * *}$ \\
\hline
\end{tabular}

Note: *** 1\% significance level, **5\% significance level, *10\% significance level.

Source: Computed by the authors.

\section{Figure 3}

NARDL dynamic multiplier graph

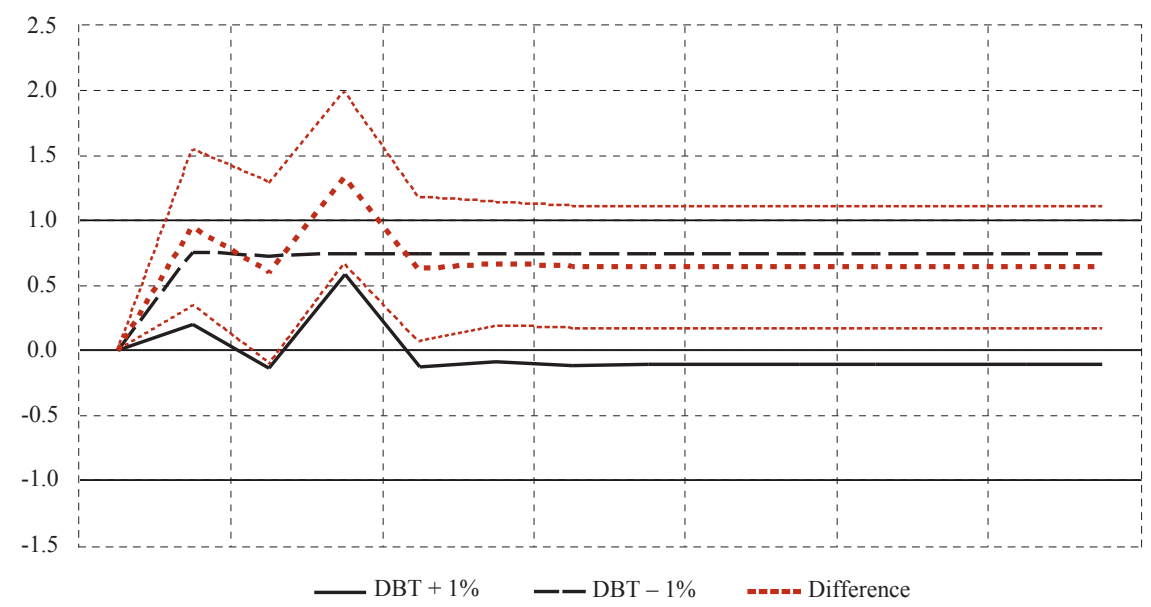

Source: Computed by the authors.

Figure 3 presents the effect of the dynamic multiplier of negative and positive changes in government debt. The solid black line captures the positive changes, which means that it gives information about the asymmetric adjustment of GDP growth to positive government debt shock at a given time horizon. The dotted black line captures the negative changes, which means that it gives information about the asymmetric adjustment of GDP growth to negative government debt shock at a given time horizon. The red dotted line depicts the difference between positive and negative shocks. Figure 3 shows that that in the short run period positive shocks are unstable compared to negative shocks. However, these shocks do not last long and they become relatively stable throughout the period (in the long run). The results in figure 3 indicate that a reduction in government debt appears to have a larger impact on GDP growth in the long run than positive government debt shock.

\section{CONCLUSION}

The purpose of this study is to investigate the asymmetric effect of government debt on Namibian GDP growth. The study used annual data for the period 1980 to 2019 and applied nonlinear ARDL method for this purpose. The results indicate that negative values of government debt have a strong impact on GDP growth 
compared to positive shocks or values. The results indicate than an increase in government debt is associated with a decrease in GDP growth. Decrease in government debt causes GDP growth to increase. The results suggest that Namibia's GDP growth responds significantly to a decrease in government debt. This is when it is compared to an increase in government debt. A reduction in government debt will therefore, result in a significant change in GDP growth in the long run. The results suggest that it is important for Namibia to keep its debt at manageable levels and achieve fiscal sustainability in order to accelerate GDP growth. Although there could be channels through which government debt impacts real GDP growth, the empirical literature suggests that there is direct causation between the two variables. Hence, this study focuses on the direct relationship between government debt and real GDP growth. An investigation of the channels through which government debt has an impact on GDP growth falls outside the scope of this study. Future studies should investigate the possible channels through which government debt affects GDP growth. We also suggest that future research should investigate and establish the debt threshold at which debt will start having an impact on real GDP growth.

\section{Disclosure statement}

The authors do not have any financial or other substantive conflict of interest that might be construed as influencing the results or interpretation of their manuscript. 


\section{REFERENCES}

1. Abd Rahman, N. H., 2012. How federal government's debt affect the level of economic growth? International Journal of Trade, Economics and Finance, 3(4), pp 323-326. https://doi.org/10.7763/ijtef.2012.v3.220

2. AEO, 2012. African Economic Outlook.

3. Amadeo, K., 2020. Public debt with its pros and cons: how to tell when its too high. The Balance, 2020.

4. Amwaama, N., 2018. An assessment of the relationship between budget deficit and economic growth in Namibia. Master of Science in economics dissertation. Windhoek: University of Namibia.

5. Baaziz, Y. [et al.], 2015. Does public debt matter for economic growth? Evidence from South Africa. Journal of Applied Business Research, 31(6), pp. 2187-2196. https://doi.org/10.19030/jabr.v31i6.9475

6. Bierens, H. J., 1997. Testing the Unit Root with Drift Hypothesis Against 'Nonlinear Trend Stationarity, with an Application to the US Price Level and Interest Rate. Journal of Econometrics, 81(1), pp 29-64. https://doi.org/10.1016/s03044076(97)00033-x

7. Bilan, I. and Ihnatov, I., 2015. Public Debt and Economic Growth: A TwoSided Story. International Journal of Economic Sciences, 4(2), pp. 24-39. https://doi.org/10.20472/es.2015.4.2.003

8. Breitung, J., 2002. Nonparametric tests for unit roots and cointegration. Journal of Econometrics, 108(2), pp. 343-363. https://doi.org/10.1016/s0304-4076 (01)00139-7

9. Brock, W. [et al.], 1996. A test for independence based on the correlation dimension. Econometric Reviews, 15(3), pp. 197-235. https://doi.org/10.1080/ 07474939608800353

10. Burhanudin, M. D. [et al.], 2017. Real effects of government debt on sustainable economic growth in Malaysia. Journal of International Studies, 10(3), pp. 161-172. https://doi.org/10.14254/2071-8330.2017/10-3/12

11. Cai, Y., 2017. Nonlinear analysis of economic growth, public debt and policy tools. Asian Economic and Financial Review, 7(1), pp. 99-108. https://doi.org/ 10.18488/journal.aefr/2017.7.1/102.1.99.108

12. Checherita-Westphal, C. and Rother, P., 2011. The impact of government debt on growth: an empirical investigation for the Euro Area. Revue Economique, 62(6), pp. 1015-1030. https://doi.org/10.3917/reco.626.1015

13. Deloitte, 2019. Namibian debt markets: unpacking public and SOE debt financials.

14. Eberhardt, M. and Presbitero, A. F., 2015. Public debt and growth: Heterogeneity and non-linearity. Journal of International Economics, 97(1), pp. 45-58. https://doi.org/10.1016/j.jinteco.2015.04.005

15. ECORYS, 2018. Fiscal Space for Children: An Analysis of Options in Namibia. Rotterdam: Ecorys.

16. Égert, B., 2012. Public Debt, Economic Growth and Nonlinear Effects: Myth or Reality? OECD Economics Department Working Papers, No. 993. http:// dx.doi.org/10.1787/5k918xk8d4zn-en 
17. Hussain, M. E, Haque, M. and Igwike, R. S., 2015. Relationship between Economic Growth and Debt: An Empirical Analysis for Sub-Saharan Africa. Journal of Economics and Political Economy, 2(2), pp. 262-275.

18. Kaakunga, E., 2006. The impact of fiscal policy on economic growth in Namibia. South African Journal of Economic and Management Sciences, 9(1), pp. 102-112.

19. Misztal, P., 2010. Public debt and economic growth in the European Union. Journal of Applied Economic Sciences, 5(3(13)/Fall 2010), pp. 292-303.

20. Nakale, S., Sikanda, M. and Mabuku, M., 2015. Fiscal policy and the national economy: aligning public expenditure to medium term development plan for socio-economic development. National Planning Commission Working Paper, NPC WP 01/15.

21. Pegkas, P., 2018. The effect of government debt and other determinants on economic growth: the Greek experience. Economies, 6(10), pp. 1-19. https:// doi.org/10.3390/economies6010010

22. Pesaran, M. H., Shin, Y. and Smith, R. J., 2001. Bounds testing approaches to the analysis of level relationships. Journal of Applied Econometrics, 16(3), pp. 289-326. https://doi.org/10.1002/jae.616

23. Reinhart, C. M. and Rogoff, K. S., 2010a. Growth in a time of debt. NBER Working Paper, No. 15639.

24. Reinhart, C. M. and Rogoff, K. S., 2010b. Growth in a time of debt. American Economic Review: Papers and Proceedings, 100(2), pp. 573-578. https://doi. org/10.1257/aer.100.2.573

25. Reinhart, C. M. and Rogoff, K. S., 2011. A decade of debt. NBER Working Paper, No. 16827.

26. Sherbourne, R., Nampila, T. and du Preez, R., 2002. Maintaining Economic Independence: Government Debt and Fiscal Sustainability. Institute for Public Policy Research (IPPR) Briefing Paper, No. 13.

27. Shin, Y., Yu, B. C. and Greenwood-Nimmo, M., 2014. Modelling asymmetric cointegration and dynamic multipliers in a nonlinear ARDL framework. In: R. Sickels and W. Horrace, eds. Festschrift in honor of Peter Schmidt: Econometric methods and applications. New York: Springer, pp. 281-314. https:// doi.org/10.1007/978-1-4899-8008-3_9

28. Zaaruka, B. P., 2007. Public debt and economic growth in Namibia. the threshold effect. Harare: MEFMI.

29. Zaaruka, B. B., Ndove, T. and Tjipe, T., 2004. Central government debt sustainability. Bank of Namibia Working Paper Series, 8/4/2/WP 1/2004. 